\title{
Flood Inundation Map Library, Fort Kent, Maine
}

Floods are the most widely occurring and costly natural hazard in the United States. Although maps of theoretical floods associated with given recurrence intervals or exceedance probabilities for a town are often available in the form of Flood Insurance Rate Maps (FIRMs), flood inundation maps show the inundated area for actual and forecast flood stages - filling the gap between maps made for regulatory purposes and maps delineating floods in real time. Flood inundation maps make current flood stages provided by the U.S. Geological Survey, and peak-forecast flood stages projected by the National Weather Service relevant to the public; assist emergency-management workers to evaluate risk, prioritize relief efforts for people and property in flood-prone areas, and are a powerful tool for use in response, mitigation, and damage assessments.

\section{Introduction}

Severe flooding occurred in northern Maine from April 28 to May 1, 2008, and damage was extensive in the town of Fort Kent (Lombard, 2010). Aroostook County was declared a Federal disaster area on May 9, 2008. The extent of flooding on both the Fish and St. John Rivers during this event showed that the current Federal Emergency Management Agency (FEMA) Flood Insurance Study (FIS) and Flood Insurance Rate Map (FIRM) (Federal Emergency Management Agency, 1979) were out of date. The U.S. Geological Survey (USGS) conducted a study to develop a flood inundation map library showing the areas and depths for a range of flood stages from bankfull to the flood of record for Fort Kent to complement an updated FIS (Federal Emergency Management Agency, in press).

Hydrologic analyses that support the maps include computer models with and without the levee and with various depths of backwater on the Fish River. This fact sheet describes the methods used to develop the maps and describes how the maps can be accessed.

\section{Inputs Necessary for Flood Inundation Mapping}

Flood surveying and documentation (Lombard, 2010) and the field work for a new FEMA FIS and FIRM provided many of the elements needed to develop flood inundation maps.

\section{Lidar Elevation Data}

Light detection and ranging (lidar) technology supports the rapid collection of high-accuracy elevation data for large areas. Lidar uses an airplane equipped with laser range finders that pulse tens of thousands of times a second and a

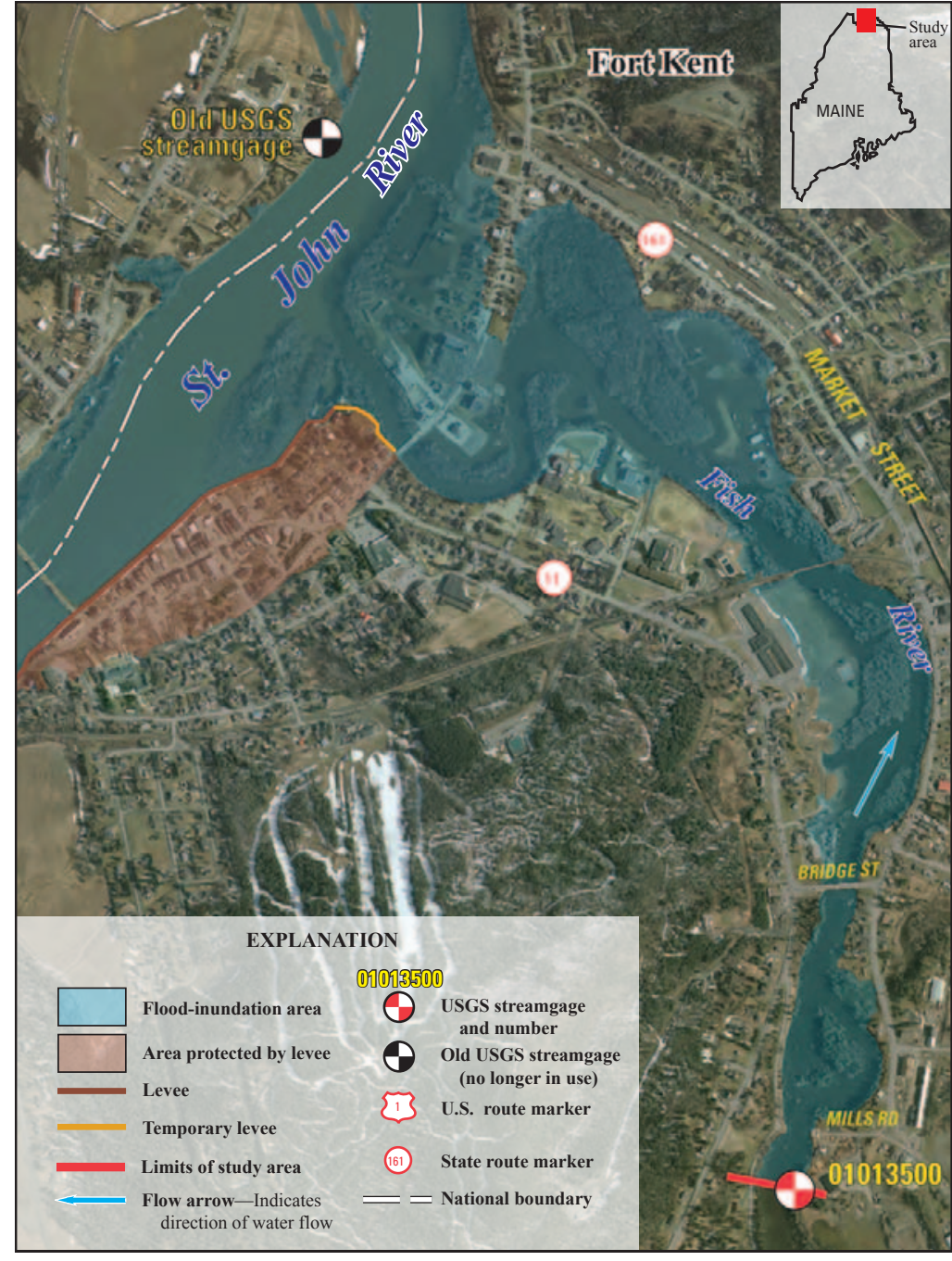

Figure 1. Area of flood inundation, Fort Kent, Maine, when the Fish River streamgage 01013500 is at a flood stage of 14.3 feet.

high-precision global positioning system (GPS). The result is topographic data with a vertical accuracy equivalent to 2-foot contour intervals. Topographic maps with this level of detail provide elevation data for the banks and flood plains along a river for both hydraulic models and flood mapping.

\section{Surveyed Elevation Data}

High water marks were surveyed following the flood; the survey provided calibration points for updating the hydraulic models of these rivers. Additional field data included elevation data measured with a total-station theodolite and underwater depths measured with 


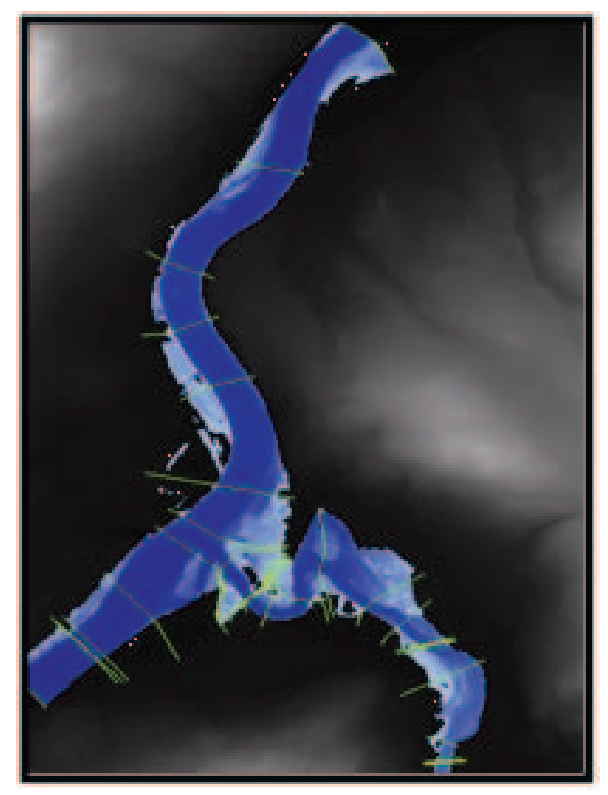

Figure 2. Lidar data for Fort Kent, Maine, 2009. (Lidar, light detection and ranging)

an Acoustic Doppler Current Profiler (ADCP) referenced to the elevation of the water surface at the time of the survey. Underwater and channel-bank field-survey data were merged with lidar data to create a final base map of high-precision elevation data.

\section{Hydraulic Model}

A Hydrologic Engineering Centers River Analysis System ( HEC-RAS) step-backwater model (U.S.Army Corps of Engineers, 2001) calibrated with highwater marks from the 2008 flood provided the elevations used to create flood boundaries and flood-depth grids for the St. John and Fish Rivers.

\section{Flood-Forecast Streamgages}

The gages on the St. John River below the Fish River at Fort Kent (USGS streamgage 01014000 , not shown on fig. 1) and on the Fish River near Fort Kent (USGS streamgage 01013500) are both used as flood-forecast streamgages by the National Weather Service (National Oceanic and Atmospheric Administration, 2010). The current and forecasted water levels are linked to the flood-inundation maps.

\section{Interaction of St. John and Fish Rivers}

Flood inundation maps for Fort Kent include flood inundation boundaries and

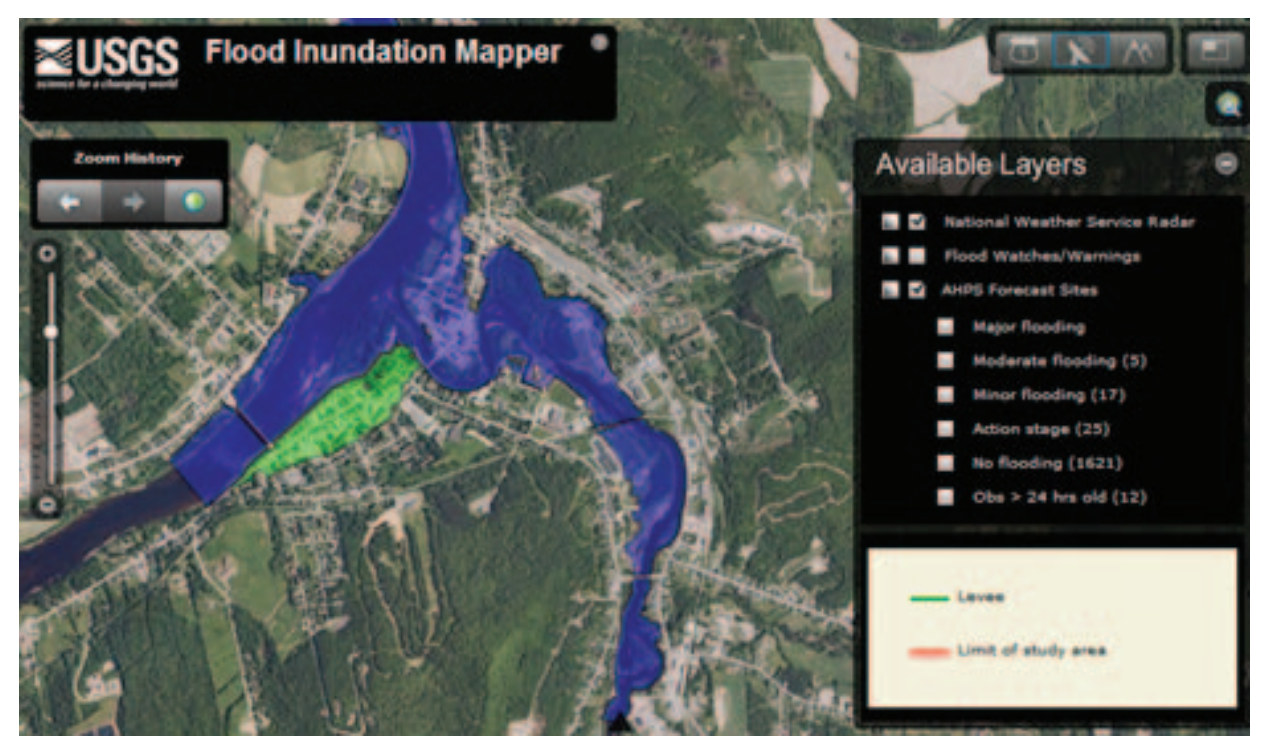

Figure 3. U.S. Geological Survey National Flood Inundation Mapper showing Fort Kent, Maine, and accessed at http://wim.usgs.gov/FIMI/.

depths for both the St. John and Fish Rivers. Backwater from the St. John River affects flood elevations on the Fish River, with the greatest interaction at the mouth. The flood inundation map library consists of a set of maps developed at 1-foot contour intervals for a total of nine stages (20.6 to 28.6 feet) at the St. John River streamgage in Fort Kent (01014000) and for a total of seven stages (8.3 to 14.3 feet) at the Fish River streamgage at Fort Kent (01013500). The user can select the map that best matches current or forecast stages at the St. John and Fish River streamgages to see the areal extent of expected inundation.

\section{Maps Available in Multiple Formats}

The flood inundation map library for Fort Kent is available to water managers and the public in multiple formats: downloadable geographic information system (GIS) file format, keyhole markup language (KML) format, and portable document format (PDF). The Fort Kent flood inundation map library is also available through the USGS Flood Inundation Mapper at http://wim.usgs.gov/FIMI/ (fig. 3). This interactive tool allows the user to select maps according to flood stages at USGS streamgaging stations or NWS flood-warning forecasts. All maps and supporting documentation are available at: http://water.usgs.gov/osw/ flood_inundation/projects/fort-kent/.

\section{References Cited}

Federal Emergency Management Agency, 1979, Flood insurance study, Town of Fort Kent, Aroostook County, Maine: Washington, D.C., December 1979, 19 p.

Lombard, P.J., 2010, Flood of April and May 2008 in northern Maine: U.S. Geological Survey Scientific Investigations Report 2010-5003, 17 p. (Also available at http://pubs.usgs.gov/sir/2010/5003/.)

Lombard, P.J., 2011, Flood inundation maps for the St. John and Fish Rivers in Fort Kent, Maine: U.S. Geological Survey Scientific Investigations Map 3157, 8 p.

National Oceanic and Atmospheric Administration, 2010, National Weather Service Advanced Hydrologic Prediction Service, accessed October 10, 2010 at http://water.weather.gov/ahps/.

U.S. Army Corps of Engineers, 2001, Hydrologic Engineering Center, River Analysis System (HEC-RAS), version 4.0 .

—By Pamela J. Lombard

For more information, please contact:

Robert Lent, Director

USGS Maine Water Science Center

196 Whitten Road

Augusta, Maine 04330

Telephone: (207) 622-8201

E-mail: dc_me@usgs.gov 